\title{
Digital Learning Ecosystem Involving STEAM Gamification for a Vocational Innovator
}

\author{
J. Kummanee, P. Nilsook, and P. Wannapiroon
}

\begin{abstract}
The purposes of this research were 1) to synthesize the conceptual framework of a digital learning ecosystem involving STEAM gamification to develop a vocational innovator, 2) to design and develop the model of a digital learning ecosystem involving STEAM gamification to develop a vocational innovator and 3 ) to evaluate the model of a digital learning ecosystem involving STEAM gamification to develop a vocational innovator. Seven experts were from purposive sampling which included two experts in STEAM Education, two experts in Creative Innovation Skills and three experts in Curriculum and Teaching. The research tools were the digital learning ecosystem involving STEAM gamification to develop a vocational innovator from the developed model. The results of the research shown that the digital learning ecosystem had three elements in the form of a digital learning ecosystem, a STEAM Education Approach, and gamification elements. The digital learning ecosystem included: 1) Biotic Components: (i) Teachers and Educational Personnel (ii) Students, Friends and Parents/Guardians, 2) Abiotic Components: (i) Hardware ii) Software (iii) Network (iv) Database and (v) Pedagogical Theories. The five steps of the STEAM education approach were: 1) Defining problems 2) Designing tools to solve problems from Mathematics and Technology 3) Producing instruments to solve problems 4) Testing, evaluating and improving the solutions of problems and 5) Presenting students' work or solutions to problems. The five gamification elements were: 1) Goals 2) Rules 3) Reinforcement: Rewards, Points, Achievements, Challenges, Trophies, Badges, Virtual Goods and Spaces, Levels, Leader boards 4) Times and 5) Feedback. The evaluation of the digital learning ecosystem involving STEAM gamification to develop a vocational innovator was deemed to be very much at an appropriate level.
\end{abstract}

Index Terms-STEAM education, gamification, digital learning ecosystem, innovator, innovative skills, vocational innovator.

\section{INTRODUCTION}

Human resource development makes use of important tools such as education. This is an important mission for every society in the world. A curriculum in the educational management process that is consistent with national development and is based on the dynamics of the world, will truly achieve a country's educational development objectives Courses for management learning in the 21 st century should be interdisciplinary in nature, in that the integration of various disciplines allows learners to learn from issues that occur in the real world, enabling them to apply the knowledge they have obtained from everyday life. Learning must

Manuscript received January 17, 2020; revised April 3, 2020.

J. Kummanee, P. Nilsook, and P. Wannapiroon are with the King Mongkut's University of Technology North Bangkok [KMUTNB], Thailand (e-mail: jb.kummanee@gmail.com,_ prachyanunn@kmutnb.ac.th, panitaw@kmutnb.ac.th). practice development process skills, encourage creativity, and support problem-solving skills by using technology and multimedia. In this regard, teachers themselves must have skills and abilities, and be able to design facilities for learning on the part of students, providing learners with the opportunity to seek knowledge through practice [1]. Such concepts are consistent with the important goals of the Office of the Vocational Education Commission, whose mission with regard to the management of vocational education is "Vocational education creates a nation". The aim of this mission is to provide a quality education that meets international standards, leading to an improvement in the competitiveness of the country in line with the aim of "Thailand 4.0 - a 'Value-Based Economy' policy". The most important element of education are the learners, who must be fully equipped with knowledge, skills, management skills, and other key important skills in the 21st Century. These include critical thinking skills, problem solving skills, co-operation skills, teamwork ability, information communication skills, and media literacy, intercultural understanding skills and an awareness of differences in the paradigm, computer skills, vocational skills, and learning skills. The most important qualities are innovation skills, in accordance with the objectives of the vocational development plan, 2017-2027, i.e. to produce "...graduates of vocational education and vocational training with morality, quality, in accordance with the needs of national development" [2].

STEAM Education is a learning model that was based on the concept of STEM Education which stand for Science, Technology, Engineering and Math, and adding an " $\mathrm{A}$ " for Art to become STEAM. It is a modern educational philosophy that encourages learners to engage in trial and error, think and analyze new concepts that carry real-world application, and receive other's opinions in order to build a knowledge-based instead of education from the examination alone. Innovations in the 20th Century relied on the ability of people with scientific expertise in the areas of technology, engineering, and mathematics - as outline by STEM Education. Creative innovations in modern times therefore, use the limits of the ability of art to integrate the scientific learning reflected in STEM Education. It can be said that STEAM Education was developed from STEM Education [3].

The management of teaching that achieved the atmosphere in the classroom was an important aspect of successful learning. Such an atmosphere helped to promote learning as fun, encouraged learners to learn, and enhanced communication skills between people to encourage them to study together

From the classroom learning process, gamification involved the use of mechanics, aesthetics, and game thinking 
principles as a basis for the design of activities which encouraged the target group to participate in positive behavior, enhance the learners' motivation to work together, promote learning processes and encouraging problem solving [4]. Therefore, the educational management model incorporating gamification aimed to apply the concepts and mechanics of gaming to motivate the students to be motivated in terms of learning, and to participate in a fun learning process, creating a good learning atmosphere. Teamwork helped students understand the complex, and made it easy to understand.

The goals and processes of learning how to manage such studies and the use of gimmicks, meant that the concepts and processes in planning process, learning management, and organizing activity work procedures and tools of both STEAM and gamification were integrated. approach involving appropriate methods. Both in form, planning process, learning management, and organizing activities, with procedures and tools. Involved the use of resources for teaching and learning that were appropriate within the context of learning management in various academic fields. It allowed the learning management process to develop, and meant that teachers were able to develop students' creative and innovative skills efficiently.

As mentioned previously, using the digital learning ecosystem involving STEAM gamification to develop a vocational innovator is suitable for vocational education in that it focuses on students' skills, allowing them to integrate their knowledge of science, learning, and working. It allows them to apply their knowledge to solve problems in their daily lives to make them valuable vocational innovators in society.

\section{RESEARCH OBJECTIVE}

The research was conducted in three phases as follows:

1) To synthesize the conceptual framework of a digital learning ecosystem involving STEAM gamification to develop a vocational innovator.

2) To design and develop the model of a digital learning ecosystem involving STEAM gamification to develop a vocational innovator.

3) To evaluate the model of a digital learning ecosystem involving STEAM gamification to develop a vocational innovator.

\section{RESEARCH METHODOLOGY}

The research was conducted in three phases as follows:

Phase 1: An analysis of a digital learning ecosystem involving STEAM gamification to develop a vocational innovator by reviewing documents, searching the literature and related research with regard to the digital learning ecosystem, STEAM education and gamification.

Phase 2: A development of a digital learning ecosystem involving STEAM gamification to develop a vocational innovator.

Phase 3: An evaluation of digital learning ecosystem involving STEAM gamification to develop a vocational innovator.

\section{RESUlts}

Phase 1: The results of the synthesis of documents and research to find the elements of the digital learning ecosystem by manipulating the learning process to develop vocational education.

1) The results of the synthesis of the concept framework of the digital learning ecosystem by using the digital learning ecosystem involving STEAM gamification to develop a vocational innovator

The conceptual framework of the research is shown in Fig 1.

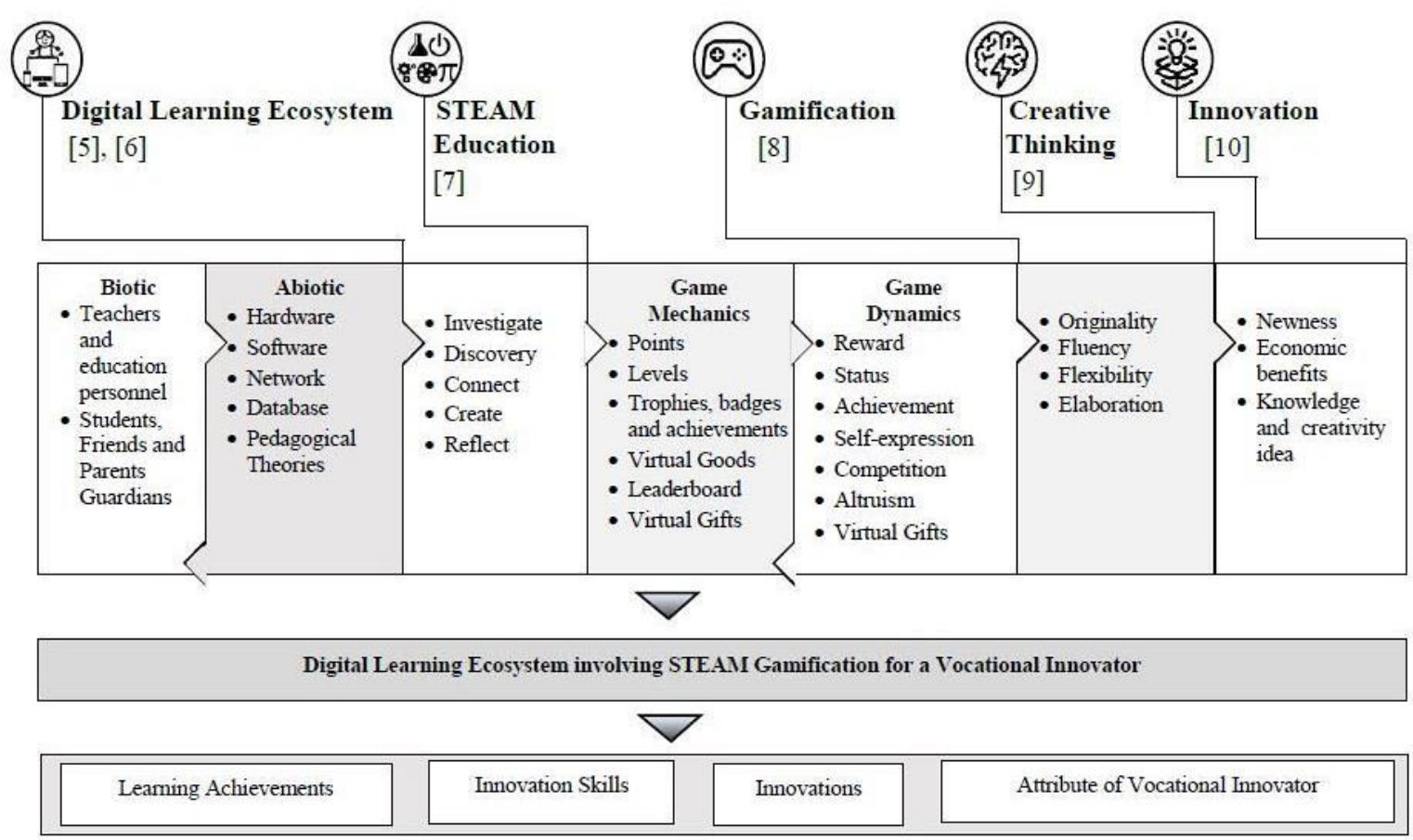

Fig. 1. The conceptual framework of the digital learning ecosystem involving STEAM gamification to develop a vocational innovator. 
Digital learning ecosystem involving STEAM gamification learning management was used in order to develop this vocational education innovator. It is associated with the development of a teaching and learning system that is suitable for vocational education, focusing on the students' integrated knowledge-based skills which is the valuable characteristics of vocational innovator. In order to explain the conceptual framework of the research as shown in Fig. 1, it must be appreciated that the proposed conceptual framework has a number of important components, namely:

STEAM Education: Teaching and learning by integrating five branches of learning in the form of $\mathrm{S}$ (Science), $\mathrm{T}$ (Technology), E (Engineering), A (Arts), and M (Mathematics). The aim is to develop a range of skills in order to apply knowledge to solving real-life problems, to create new processes or products that are artistically beautiful, and which are useful both for work and daily living. The learning process has five steps: i) Investigation, ii) Discovery, iii) Connection, iv) Creation, and v) Reflection.

The gamification of the teaching and learning process involves applying concepts and mechanics of gaming in order to motivate learners and to encourage them to participate in the classroom, and to help learners understand complex issues and to make them easier. The game mechanics consists of i) Game Mechanics including Points, Levels, Trophies, badges and achievements, Virtual Goods, Leaderboard, Virtual Gifts, Virtual Goods, Leaderboard, and Virtual Gifts; and ii) Game Dynamics including Reward, Status, Achievement, Self-Expression, Competition, and Altruism.

STEAM Gamification: This involves a learning management model aimed at creating an positive atmosphere in the classroom, allowing students to be creative in term of their skills, to be innovative in terms of achievement, learning, innovation, and promoting teamwork skills.

The digital learning ecosystem is a set of relationships incorporating biotic components and abiotic factors. They work together to create learning, with two main components: i) biotic components which are divided into two parts: users (actors: human), and digital content, including users who interact with digital technology such as teachers and educational personnel, learners, students, friends, parents/ guardians, and digital content, including all kinds of digital content related to learning, such as learning tools, tools used to create content, educational games, browsers, simulations, and educational information. ii) abiotic components, including hardware, software, databases, networks, and pedagogical theories.

Innovation skills: This refers to the skills of a person who is creative in the development of concrete innovations such as creating or developing inventions, working or solving problems efficiently, or who is innovative in terms of abstract features such as new work processes, which make the workflow develop, improves the workflow by making it faster, more convenient, and easier to practice. It involves creating something useful, valuable to society, and of commercial value.

A vocational innovator is a vocational learner with three skills in the form of knowledge, behavior, and attitude with creativity Such an individual is able to apply the knowledge obtained, to invent, and to innovate for use in everyday living, or to create or solve social problems.

Creative innovation is the creativity needed to develop new inventions. That can be in the form of products, processes, or services, etc. It involves creating value, and benefitting people, the economy and society.

Learning achievement: This is measured by points earned through the use of the achievement test.

\section{2) Process of STEAM education}

This is the synthesis of research and related documents in order to find elements of the STEAM education process as shown in Table I.

TABLE I: THE COMPARISON OF STEAM PROCESSES

\begin{tabular}{|c|c|c|c|c|c|}
\hline Science & Technology & Engineering & Arts* & Mathematics & STEAM \\
\hline Ask questions & $\begin{array}{l}\text { Become aware of the } \\
\text { web of technological } \\
\text { systems on which } \\
\text { society depends }\end{array}$ & Define problems & $\begin{array}{l}\text { Think of the Problem } \\
\text { at hand and how best } \\
\text { to express it. }\end{array}$ & $\begin{array}{l}\text { Make sense of } \\
\text { problems and } \\
\text { persevere in solving } \\
\text { them }\end{array}$ & Define problems \\
\hline Develop and use models & & $\begin{array}{l}\text { Develop and use } \\
\text { models }\end{array}$ & & $\begin{array}{l}\text { Model with } \\
\text { mathematics }\end{array}$ & $\begin{array}{l}\text { Designing to solve } \\
\text { problems from } \\
\text { Mathematics and } \\
\text { Technology }\end{array}$ \\
\hline $\begin{array}{l}\text { Plan and carry out } \\
\text { investigations }\end{array}$ & $\begin{array}{l}\text { Learn how to use new } \\
\text { technologies as they } \\
\text { become available }\end{array}$ & $\begin{array}{l}\text { Plan and carry out } \\
\text { investigations }\end{array}$ & & $\begin{array}{l}\text { Use appropriate tools } \\
\text { strategically }\end{array}$ & $\begin{array}{l}\text { Development Tools } \\
\text { to solve problems }\end{array}$ \\
\hline $\begin{array}{l}\text { Analyze and interpret } \\
\text { data }\end{array}$ & & $\begin{array}{l}\text { Analyze and interpret } \\
\text { data }\end{array}$ & $\begin{array}{l}\text { Discuss and } \\
\text { Brainstorm on how to } \\
\text { design and express the } \\
\text { ideas }\end{array}$ & Attend to precision & $\begin{array}{l}\text { Interpretation of data } \\
\text { analysis }\end{array}$ \\
\hline Construct explanations & & Design solutions & $\begin{array}{l}\text { On stage, on canvas or } \\
\text { on the table, to create } \\
\text { Prototypes }\end{array}$ & $\begin{array}{l}\text { Look for and make use } \\
\text { of structure }\end{array}$ & $\begin{array}{l}\text { Design methods } \\
\text { using project to solve } \\
\text { problems }\end{array}$ \\
\hline
\end{tabular}




\begin{tabular}{|c|c|c|c|c|c|}
\hline Science & Technology & Engineering & Arts* & Mathematics & STEAM \\
\hline $\begin{array}{l}\text { Engage in argument } \\
\text { from evidence }\end{array}$ & $\begin{array}{l}\text { Make informed } \\
\text { decisions about } \\
\text { technology given its } \\
\text { relationship to society } \\
\text { and the environment }\end{array}$ & $\begin{array}{l}\text { Engage in argument } \\
\text { from evidence }\end{array}$ & & $\begin{array}{l}\text { Construct viable } \\
\text { arguments and critique } \\
\text { the reasoning of others }\end{array}$ & $\begin{array}{l}\text { Test, evaluate, and } \\
\text { improve solutions to } \\
\text { problems or } \\
\text { workpieces }\end{array}$ \\
\hline $\begin{array}{l}\text { Obtain, evaluate, and } \\
\text { communicate } \\
\text { information }\end{array}$ & & $\begin{array}{l}\text { Obtain, evaluate, and } \\
\text { communicate } \\
\text { information }\end{array}$ & $\begin{array}{l}\text { For feedback and test, } \\
\text { to explore } \\
\text { applicability and } \\
\text { identify gaps }\end{array}$ & $\begin{array}{l}\text { Look for and express } \\
\text { regularity in repeated } \\
\text { reasoning }\end{array}$ & $\begin{array}{l}\text { Offer a solution } \\
\text { Problem-solving } \\
\text { results or workpieces }\end{array}$ \\
\hline
\end{tabular}

Source: [11], *[12].

According to Table I, we can synthesize five steps of STEAM education as follows:

- Defining problems: Study information from many resources to define problems.

- Designing to solve problems using Mathematics and Technology: Apply Technology and Mathematics to design methods to solve problems.

- Producing instruments to solve problems or using projects to solve problems: Designing instruments according to the model.

- Testing, evaluating and improving the solutions to problems: Applying instruments and solving problem activities to test then improve them.

- Presenting students' works/solutions to problems: students will present the methods for solving problems and present the innovation to transfer knowledge from each student.

\section{3) Gamification elements}

From the synthesis of the components of the game in teaching and learning to promote learning by developing a learning atmosphere that promotes self-learning and teamwork as shown in Table II.

\begin{tabular}{|c|c|c|c|c|c|c|c|c|c|c|}
\hline Gamification elements & 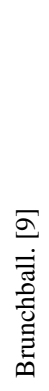 & 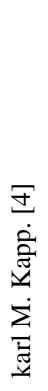 & 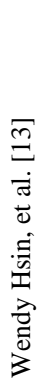 & 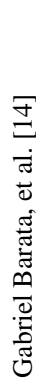 & 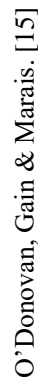 & 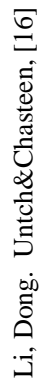 & $\begin{array}{l}\infty \\
\infty \\
\dot{\sigma} \\
\tilde{\omega} \\
\ddot{\Phi} \\
\Xi \\
\Xi\end{array}$ & 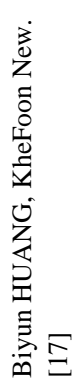 & $\begin{array}{l}\underset{\infty}{\Xi} \\
\dot{\mathscr{D}} \\
\stackrel{\Xi}{\Xi} \\
\stackrel{\Xi}{\Xi}\end{array}$ & 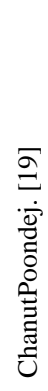 \\
\hline 1. Goals & $\checkmark$ & $\checkmark$ & $\checkmark$ & $\checkmark$ & $\checkmark$ & $\checkmark$ & $\checkmark$ & $\checkmark$ & $\checkmark$ & $\checkmark$ \\
\hline 2. Rules & $\checkmark$ & $\checkmark$ & $\checkmark$ & $\checkmark$ & $\checkmark$ & $\checkmark$ & $\checkmark$ & $\checkmark$ & $\checkmark$ & $\checkmark$ \\
\hline $\begin{array}{l}\text { 3. Reinforcement (Reward, Points, Achievements, Challenges, } \\
\text { Trophies, Badges, Virtual Goods and Spaces), Level, Leader } \\
\text { boards) }\end{array}$ & $\checkmark$ & $\checkmark$ & $\checkmark$ & $\checkmark$ & $\checkmark$ & $\checkmark$ & $\checkmark$ & $\checkmark$ & $\checkmark$ & $\checkmark$ \\
\hline 4. Times & $\checkmark$ & $\checkmark$ & $\checkmark$ & $\checkmark$ & $\checkmark$ & $\checkmark$ & $\checkmark$ & $\checkmark$ & $\checkmark$ & $\checkmark$ \\
\hline 5. Feedbacks & $\checkmark$ & $\checkmark$ & $\checkmark$ & $\checkmark$ & $\checkmark$ & $\checkmark$ & $\checkmark$ & $\checkmark$ & $\checkmark$ & $\checkmark$ \\
\hline 6. Conflict, Competition or Cooperation & & $\checkmark$ & $\checkmark$ & & & & & $\checkmark$ & & \\
\hline 7. Story, Aesthetic, Sound effect & & $\checkmark$ & & $\checkmark$ & & & & & & $\checkmark$ \\
\hline
\end{tabular}

From Table II, the synthesis of the components of the game found that there are five elements. These are as follows: i) Goals refers to the purpose of the game in terms of creating a challenge for the player to win the game, ii) Rules means how to play, the scoring, and the conditions that players must follow, iii) Reinforcement consists of rewards, the accumulation of points, achievements, levels. The leader board indicates what players receive when achieving goals which the players can project their ranking at real time. iv) Times relate to motivating players to undertake activities or to perform. This trains management to allocate time, which is an important success factor, and v) Feedback is a reflection of the idea. It relates to player action that is wrong or correct in order to guide the player in terms of continuing the activity appropriately.

Phase 2: A development of the digital learning ecosystem involving STEAM gamification for the development of a vocational innovator. The research results for the phase related to:

The digital learning ecosystem. This consists of i) the biotic component, including system users such as teachers and educational personnel, and students, friends and family; and ii) the abiotic component including hardware, software, network, database, and pedagogical theories.

STEAM Gamification consists of i) problem definition, ii) problem-solving design, iii) problem-solving tool construction, iv) test procedure interpretation and improvement of problem-solving methods, and v) presentation of stage/solution methods.

The gamification elements consist of i) Goals, ii) Rules, iii) Reinforcement, iv) Times, and v) Feedback. 


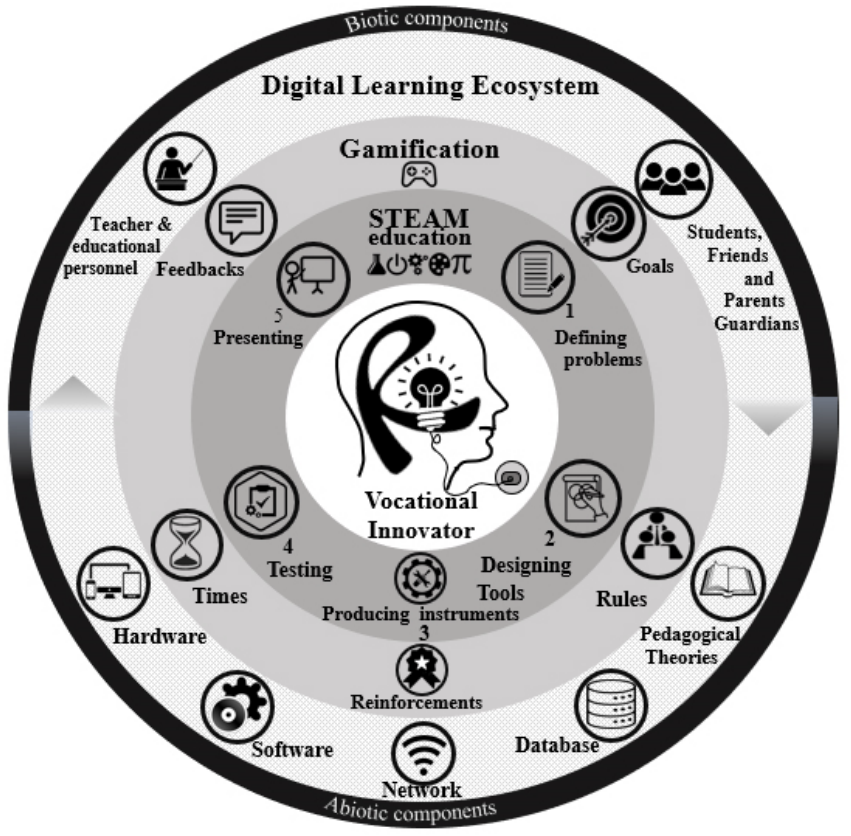

Fig. 2. The model of digital learning ecosystem involving STEAM gamification for vocational innovator development.

Fig. 2 show the digital learning ecosystem involving STEAM gamification for vocational innovator development. This is as follows:

The digital learning ecosystem is a link between the abiotic component and the abiotic component in the system. This includes teachers who transfer knowledge and facilitate learners to utilize the components of digital systems most effectively.

Carrying out classroom learning activities, using educational learning processes which focus on integrating science, and teamwork to develop innovative skills, consists of five steps:

1) Problem definition: by researching and collecting data from various learning sources in order to define real problems. This includes: i) Problem definition, ii) problem solving design, iii) problem solving tool construction, iv) test procedure interpretation and improvement of problem-solving methods, and v) presentation stage/solution methods.

2) Designing tools: This involves problem solving process design by using mathematics and technology. It is the the application of technology and knowledge in mathematics to design solutions.

3) Producing instruments: Test procedure interpretation and improvement of problem-solving methods in order to develop tools according to the form created.

4) Testing: interpretation, and improvement procedures. These are the tools or solutions that are designed to solve problems, and suggest effective improvements.

5) Presenting: Presentation process / problem solving methods. Students present a solution to problems or present innovations created in order to exchange knowledge between learners.

In carrying out the learning activities, teachers use the gamification mechanism to stimulate interest and fun in the classroom. This mechanism consists of the following five steps:

1) Goals: The instruction of each game may differ, but the similarities of all game are the goals to overcome the situation, to solve puzzles, or to meet specific criteria. The game designer sets out to cause challenges that help players move forward. When achieving a goal ends the game, sometimes it may be necessary to include sub-goals, which can lead to a big target in order to achieve continuous play, so that the game does not end too soon.

2) Rules: The game must include rules in terms of how to play, how to score, or game conditions. These are described for the players to follow. Game designers must explain the rules clearly.

3) Conflict, Competition, or Cooperation: Conflict exists by destroying or hindering the opponent. The element of competition will increase the player's efficiency when it comes to overcoming opponents. Cooperation involves working in a team to overcome obstacles, and to achieve common goals.

4) Time is the driving force behind activities or operations. This may cause players pressure and lead to stress thus training learners to work within time constraints. Therefore, students must learn to allocate and manage time. This is an important success factor.

5) Rewards are something that players will receive, when achieving their goals. These may be shown on a leader board. Reward is important in order to motivate players to compete well by achieving a high score.

6) Feedback relates to correct action, or to wrong action, and suggests the appropriate way to carry out an activity.

7) Levels are the aspects that generate continuous challenges, with players progressing to higher levels in order to achieve new goals. Players will be under increasing pressure, making them use their experience and skills obtained from previous levels to finish the game. Sometimes, players do not always have to start from level 1. There may be a selection of easy, medium, or difficult levels in order to ensure that they suitable for the ability of the game players, or sometimes the level may be determined the players themselves, by using experience points they may have gained. Collecting experience at a certain point will increase the experience level and these will become higher throughout the game. 
Phase 3: An evaluation of digital learning ecosystem involving STEAM gamification for vocational innovator development. The research result for this phase can be seen in Table III. The appropriateness of the digital learning ecosystem involving STEAM gamification for vocational innovator development was deemed to be at a very appropriate level $(\bar{x}=4.74$, S.D. $=0.445)$. Considering each item, the highest rating item in terms of appropriateness was at a very appropriate level $(\bar{x}=4.86$, S.D. $=378)$, while even the lowest rating was viewed as being at a very appropriate level $(\bar{x}=4.57$, S.D. $=535)$.

TABLE III: THE RESULT OF ANALYSIS FOR APPROPRIATENESS FOR DIGITAL LEARNING ECOSYSTEM INVOLVING STEAM GAMIFICATION FOR VOCATIONAL INNOVATOR DEVELOPMENT

\begin{tabular}{|c|c|c|c|}
\hline Descriptions & $\bar{x}$ & S.D. & $\begin{array}{c}\text { Level of } \\
\text { appropriateness }\end{array}$ \\
\hline 1. Principles and ideas are used as a basis for the design of the learning processes. & 4.86 & 0.378 & Very much \\
\hline 2. Elements of learning processes are designed according to the main elements of the methods of teaching. & 4.57 & 0.535 & Very much \\
\hline $\begin{array}{l}\text { 3. Learning Process of digital learning ecosystem involving STEAM gamification for vocational innovator } \\
\text { development. }\end{array}$ & 4.86 & 0.378 & Very much \\
\hline $\begin{array}{l}\text { 4. Digital learning ecosystem involving STEAM gamification for vocational innovator development are appropriate } \\
\text { to the creative innovation skills of vocational students. }\end{array}$ & 4.71 & 0.488 & Very much \\
\hline $\begin{array}{l}\text { 5. Steps and activities of the digital learning ecosystem involving STEAM gamification for vocational innovator } \\
\text { development are appropriate for creative innovation skills and learning development. }\end{array}$ & 4.86 & 0.478 & Very much \\
\hline 6. Digital learning ecosystem involving STEAM gamification for vocational innovator development can adapt to daily life. & 4.57 & 0.535 & Very much \\
\hline Total Average & 4.74 & 0.445 & Very much \\
\hline
\end{tabular}

Source: [20], [21]

From Table III the digital learning ecosystem of STEAM gamification for vocational innovator is appropriate. At the very much level the mean value is between $4.57-4.86$ and the standard deviation is between $0.378-0.535$.

\section{CONCLUSION}

According to analysis of the related content, the STEAM education approach consist of five steps: i) Defining problems, ii) Designing methods of solving problems from Mathematics and Technology, iii) Producing instruments or projects with regard to problem solving activities, iv) Testing, evaluating and improving the solutions to problems, and v) Presenting students' work or solutions to problems.

The gamification elements consist of five steps: i) Goals, ii) Rules, iii) Reinforcement including rewards, points, achievements, challenges, trophies, badges, virtual goods and spaces, levels, leader boards, iv) Times, and v) Feedback. Gamification is used as a tool to motivate students to participate in learning activities and to challenge students to improve their skill continuously. In accordance with Jampong and Prammanee [20], who researched a STEAM education exercise to create the work "energy in daily life", the results concluded that the proficiency of exercises with regard to creating the work was 80.76/81.54 which was higher than the standard 80/80. The difference between pre-test and post-test outcomes was statistically significant at a 0.05 level, and competency in creating work after undertaking the exercise was rated as good. The use of STEAM education to create work was evaluated in five steps namely i) Identifying problems, iI) Searching the related concepts, iii) Planning and development, iv) Experimenting and evaluating and v) Presenting the result. It was also related to the research work of Bunsan [21], who developed a teaching management program to enhance team work skills using a Gamification for Science program in the grade 10 classroom of Kalayanamith School. The results found that students who studied using gamification techniques to enhance their teamwork skills in the program writing subject, produced a difference between pre-test and post-test outcomes that were statistically significant at the 0.05 level. The comparison between team-work skills found that the team-work achievement after studying was higher than 80 percent, and statistically significant at the 0.05 level. Students who studied by using gamification techniques satisfactorily voted the learning processes as "excellent". These learning processes consisted of three steps: i) Planning, ii) Experimentation which consisted of motivation, practice, transfer knowledge, and conclusions, and iii) Observations.

According to the evaluation, the experts rated the model as being highly appropriate. As a result, this model is appropriate and can be used to enhance vocational students creativity and innovation skills.

\section{CONFLICT OF INTEREST}

The authors declare no conflict of interest.

\section{AUTHOR CONTRIBUTIONS}

J. Kummanee conducted the research, analyzed the data, and wrote the paper; P. Nilsook, and P. Wannapiroon the research consulting; all authors had approved the final version.

\section{ACKNOWLEDGMENTS}

This work is partly supported by Graduate College of King Mongkut's Institute of Technology North Bangkok (KMUTNB), Thailand.

\section{REFERENCES}

[1] S. Chanprasert, "Management of science and skills required in the $21 \mathrm{st}$ century," Inst. Promot. Teach. Sci. Technol., vol. 42, no. 185, pp. 1012, Jan. 2013

[2] Office of Vocational Education Commission. (2018). Mission Policy. [Online]. Available: http://www.vec.go.th/ Default.aspx? tabid=87

[3] T. Purcell. (2015). Fly up, up \& always with STEAM education this summer. [Online]. Available: http://steamsummerschool.eu/

[4] K. M. Kapp, The Gamification of Learning and Instruction, San Francisco: Pfeiffer, 2012, pp. 1-5.

[5] J. Reyna, "Digital teaching and learning ecosystem (DTLE): A theoretical approach for digital teaching and learning ecosystem (DTLE): A theoretical approach for online learning," in ASCILITE 
2011 - The Australasian Society for Computers in Learning in Tertiary Education, 2011, pp. 1085-1088.

[6] K. Sarnok, P. Wannapiroon, and P. Nilsook. "Digital learning ecosystem by using digital storytelling for teacher profession students," Int. J. Inf. Educ. Technol., vol. 9, no. 1, pp. 21-26, Jan. 2019.

[7] Educationcloset. (2018). STEAM. [Online]. Available: https://educationcloset.com/STEAM

[8] C. Turner, "Learn2Mine: Data science practice and education through gameful experiences," Int. J. e-Education, e-Business, e-Management e-Learning, vol. 4, no. 3, pp. 243-248, June 2014.

[9] Bunchball. (2010). Gamification 101: An introduction to the use of game dynamics to influence behavior. [Online]. Available: http://jndglobal.com/wp-content/uploads/2011/05/gamification1011.p df

[10] A. Chandrachai, "Innovation, meaning, type and importance of being a entrepreneur," J. Bus. Adm., vol. 33, no. 128, pp. 57-58, Oct.-Dec. 2010.

[11] J. A. Vasquez, M. Comer, and C. Schneider, STEM Lesson Essentials. Integrating Science, Technology, Engineering and Mathematics, New Hampshire, United States of America: Houghton Mifflin Harcourt, 2013, pp. 49-64.

[12] The UBQT Team. (2019). Design thinking through ART-based methods. [Online]. Available: https://ubqtsolutions.com/ 2015/11/28/design- thinking- through-art-based-methods/

[13] W. H.-Y. Huang and D. S. Soman, "A practitioner's guide to gamification of education," Rotman School of Management Univ. of Toronto, Canada, Dec. 2013, pp. 7-14.

[14] G. Barata, S. Gama, J. Jorge, and D. Gonçalves, "Improving participation and learning with gamification," in ACM International Conference Proceeding Series, 2013, pp. 10-17.

[15] S. O'Donovan, J. Gain, and P. Marais, "A case study in the gamification of a university-level games development course," in ACM International Conference Proceeding Series, 2013, pp. 242-251.

[16] C. Li, Z. Dong, R. H. Untch, and M. Chasteen, "Engaging computer science students through gamification in an online social network based collaborative learning environment," Int. J. Inf. Educ. Technol., pp. 72-77, Feb. 2013.

[17] B. Huang, K. F. Hew, and C. K. Lo, "Investigating the effects of gamification-enhanced flipped learning on undergraduate students' behavioral and cognitive engagement," Interact. Learn. Environ., vol. 843 , no. 25 , pp. 1-21, July 2018.

[18] I. Doumanis and S. Smith, "A framework for research in gamified mobile guide applications using embodied conversational agents (ECAs)," Int. J. Serious Games, vol. 2, no. 3, pp. 21-40, 2015.
[19] C. Poondej and T. Lerdpornkulrat, "The development of gamified learning activities to increase student engagement in learning," Aust Educ. Comput., vol. 31, no. 2, pp. 1-16, Jul. - Sep. 2016.

[20] M. Jampong and N. Prammanee, "The development of work creation through STEAM education approach on energy," EAU Herit. J. Soc. Sci. Humanit., vol. 7, no. 3, pp. 81-92, Sep-Dec 2017.

[21] T. Bunsan, "Instructional program to enhance team work skills by applying gamification technique on programming I for enrichment science class student mathayomsueksa IV kanlayanawat school," M.S thesis, Dept. Computer Educ., Rajabhat Maha Sarakham Univ., Maha Sarakham, Thailand, 2017

Copyright (C) 2020 by the authors. This is an open access article distributed under the Creative Commons Attribution License which permits unrestricted use, distribution, and reproduction in any medium, provided the original work is properly cited (CC BY 4.0).

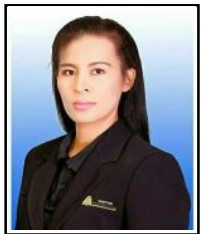

Jiraphorn Kummanee is a Ph.D. candidate in information and communication technology for education, in Faculty of Technical Education, King Mongkut's University of Technology North Bangkok [KMUTNB], Thailand.

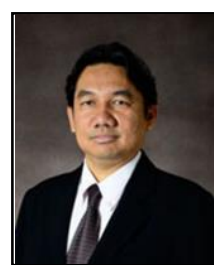

Prachyanun Nilsook is an associate professor at the Division of Information and Communication Technology for Education, King Mongkut's University of Technology North Bangkok [KMUTNB], Thailand. He currently works in the field of ICT for education. He is a member of Professional Societies in the Association for Education Technology of Thailand (AETT)

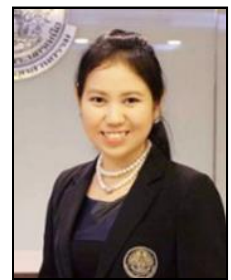

Panita Wannapiroon is an associate professor at the Division of Information and Communication Technology for Education, King Mongkut's University of Technology North Bangkok [KMUTNB], Thailand. She currently works in the field of ICT for education. she is a member of Professional Societies in the Association for Education Technology of Thailand (AETT). 